\title{
ADRA2C Gene
}

National Cancer Institute

\section{Source}

National Cancer Institute. ADRA2C Gene. NCI Thesaurus. Code C107613.

This gene is involved in the regulation of neurotransmitter release. 